\title{
Association between sleeping patterns, oral hygiene status, and self-reported academic performance among dental students
}

\author{
Khanal S, 1 (iD Shrestha S, ${ }^{\text {iD }}$ Bhattarai R ${ }^{2}$ iD \\ 'Sunita Khanal; 'Sujita Shrestha; Lecturer, Department of Community Dentistry, Kantipur Dental College, Basundhara, \\ Kathmandu, Nepal; ${ }^{2}$ Rosina Bhattarai, Lecturer, Department of Community Dentistry, College of Medical Sciences, \\ Bharatpur, Chitwan, Nepal.
}

\begin{abstract}
Background: Sleep is very important for normal functioning and overall development of the body for all. Information on association between sleeping patterns, oral hygiene status, and self-reported academic performance among dental students is not available in Nepal.

Objectives: The aim of the study was to assess the association between sleeping patterns, oral hygiene status, and selfreported academic performance among dental students.

Methods: Analytical cross-sectional study was conducted among second year to final year students of Kantipur Dental College from January to December 2020. Ethical approval was obtained from the institutional review committee of Kantipur Dental College before collecting the data. Convenience sampling was used. Data collection was done by using self-administered, Pittsburgh Sleep Quality Index (PSQI) questionnaire for assessing sleep quality. For assessing oral hygiene status, Greene and Vermillion OHI-S index was used. Academic performance was measured by the performance of the students in their previous university exam. Data were entered in Microsoft Excel and analysis was done by using SPSS version 20 and $p<0.05$ was considered to be statistically significant.

Results: Altogether 138 students participated in the study. Self-reported sleep quality was fairly good among 82 (59.4\%) students but the actual sleep quality determined by PSQI was good among 92 (67\%) students. Mean hours of actual sleep of participants was $7 \pm 1.52$ hours. The association between sleeping patterns, academic performance, and oral hygiene status was found to be statistically insignificant.

Conclusion: The sleeping patterns, oral hygiene status, and academic performance had no significant association.
\end{abstract}

Key words: Academic performance; Dental students; Oral hygiene status; Sleeping patterns.

\section{Access this article online}

Website: www.jkmc.com.np

DOI: https://doi.org/10.3126/jkmc.v10i1.38967

\section{HOW TO CITE}

Khanal S, Shrestha S, Bhattarai R. Association between sleeping patterns, oral hygiene status, and self-reported academic performance among dental students. J Kathmandu Med Coll. 2021;10(1):23-7.

Address for correspondence

Dr. Sunita Khanal

Lecturer, Department of Community Dentistry,

Kantipur Dental College, Basundhara,

Kathmandu, Nepal

E-mail: khanal.sunita729@gmail.com

Copyright $\odot 2021$ Journal of Kathmandu Medical College (JKMC) ISSN: 2019-1785 (Print), 2091-1793 (Online) Attribution-Non Commercial 4.0 International License.

\section{INTRODUCTION}

leep is pivotal to learning and practice as well as $\checkmark$ physical and mental health and is an inseparable part of human health and life. ${ }^{1}$ Studies have shown that onethird of adults suffer from sleep problems and that the students sleep less compared to the general population because of academic stress. High failure rates and poor academic performance is also associated with poor sleep quality. ${ }^{2}$ Sleep is very essential to everybody's health. Both health and performance are influenced by sleep. ${ }^{3}$ For a successful academic and economically prosperous career, sleep is undoubtedly an important aspect. ${ }^{4}$ Lack of concentration and attention during class is also associated with sleep deficit. ${ }^{5}$

For students, maintenance of oral hygiene, academic performance, and cognitive functioning are affected by sleep. Therefore sleep quality and pattern should be 
considered as an important issue. ${ }^{6}$ Some characteristics that affect quality of sleep are snoring, hours of sleep, use of medications, use of alcohol, waking in the night, bad dreams, and environmental factors. ${ }^{7-11}$

The authors could find no study on this topic done in Nepal. The aim of this study was to assess the association between sleeping patterns, oral hygiene status, and selfreported academic performance among dental students.

\section{METHODOLOGY}

An analytical cross-sectional study was conducted among the students of Kantipur Dental College. The data was collected from the second year to final year students from between January 2020 to December 2020. Ethical approval was taken from institutional review committee of Kantipur Dental College before starting the study. The objectives were clearly explained to the students and consent was obtained from them. All the students from second year to final year who were interested to participate in the study were included. Exclusion criteria included first year students and those students who were not willing to participate in the study. Convenience sampling technique was done for selecting study participants. Sample size was calculated by using the formula, $n=Z^{2} p q / e^{2}$ where $p$ (prevalence of poor sleep quality) $=35.4 \%,{ }^{12} \mathrm{e}=8 \%$ and it was calculated to be 138 .

Data collection was done by using self-administered questionnaire containing Pittsburgh Sleep Quality Index (PSQI) for assessing sleep quality. The PSQI is a selfreported questionnaire which examines the quality of sleep. It is a 19-item tool which has seven components: the first component is the subjective sleep quality, the second component is related to delay in falling asleep, the third component deals with sleep duration, fourth component is related to the efficiency and effectiveness of sleeping in patients. The fifth component deals with sleep disorders, sixth component is related to hypnotic drugs and the seventh component captures inadequate performance throughout the day. Each question is rated between zero and three. The total scores range of the seven components range from zero to 21 in which a greater score suggests poor sleep quality. In identifying good and poor sleepers, a global PSQI score $>5$ yields a sensitivity of $89.6 \%$ and a specificity of $86.5 \%$. $^{13}$

For assessing oral hygiene status, Greene and Vermillion Simplified Oral Hygiene Index (OHI-S) was used. ${ }^{14}$ Academic performance was measured by their performance in the previous university exam. The questionnaire's reliability was assessed by pretesting and use of Cronbach's alpha whose value was $>0.78$. Data collected from the questionnaires were entered in Microsoft Excel sheet and was then analysed with standard statistical software, SPSS, statistics for windows, version 20 (SPSS Inc. Chicago, III.,USA)'and descriptive analysis was done as frequency and percentage.

Chi-square test was applied for association of academic performance and sleep as well as oral hygiene status and sleep, where $p<0.05$ was considered statistically significant.

\section{RESULTS}

A total of 138 students participated in the study out of which 120 (87\%) were female and 18 (13\%) were male. Mean age of the students was $21.83 \pm 1.46$ years. The sleep quality was assessed by using self-administered, PSQI and was found to be good among 92 (67\%) students (Figure 1). Self-reported responses for sleep patterns are shown in Table 1. The oral hygiene status was assessed by using OHI-S index and it was found to be "Good" among 77 (55.8\%) students (Table 2).

Chi-square test was applied to assess the association between sleeping pattern and OHI-S which was found to be statistically insignificant with $p=0.445$ (Table 3). The association between sleeping patterns and academic performance and was found to be statistically insignificant with $\mathrm{p}=0.430$ (Table 4).

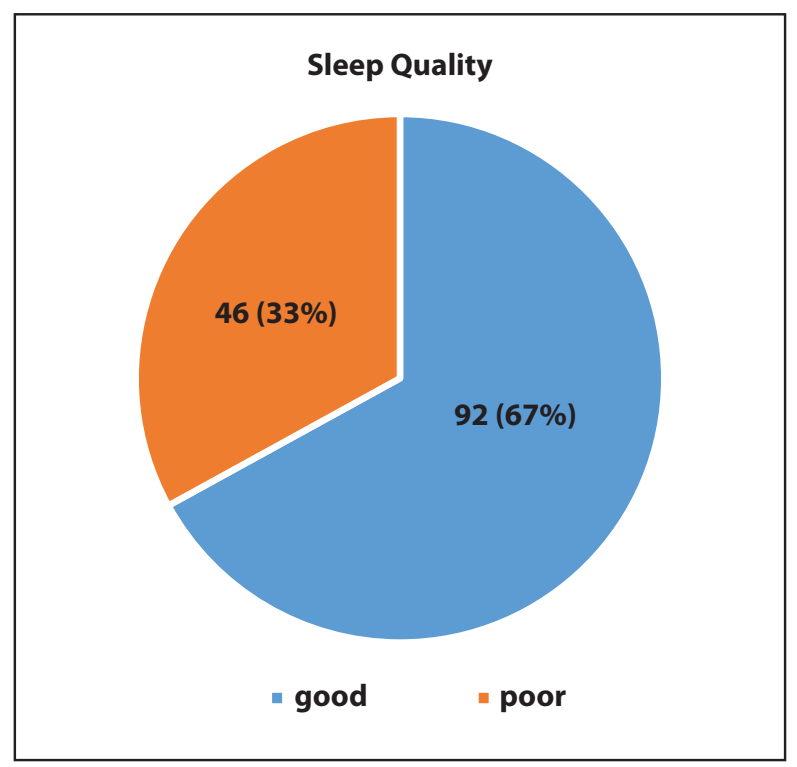

Figure 1: Sleep quality of students 
Table 1: Responses for sleep patterns

\begin{tabular}{|c|c|c|c|c|}
\hline \multirow{2}{*}{$\begin{array}{l}\text { Questions } \\
\text { During the past month, how often have you had trouble } \\
\text { sleeping because you... }\end{array}$} & \multicolumn{4}{|c|}{ Responses, n (\%) } \\
\hline & $\begin{array}{l}\text { Not during the } \\
\text { past month }(0)\end{array}$ & $\begin{array}{l}\text { Less than once } \\
\text { a week (1) }\end{array}$ & $\begin{array}{l}\text { Once or twice } \\
\text { a week (2) }\end{array}$ & $\begin{array}{l}\text { Three or more } \\
\text { times a week ( } 3 \text { ) }\end{array}$ \\
\hline a. Cannot get to sleep within 30 minutes & $65(47.1)$ & $29(21)$ & $21(15.22)$ & $23(16.67)$ \\
\hline b. Wake up in the middle of the night or early morning & $55(39.9)$ & $35(25.36)$ & $28(20.29)$ & $20(14.5)$ \\
\hline c. Have to get up to use the bathroom & $60(43.47)$ & $47(34.1)$ & $20(14.5)$ & $11(8)$ \\
\hline d. Cannot breathe comfortably & $117(84.8)$ & $17(12.3)$ & $4(2.9)$ & - \\
\hline e. Cough or snore loudly & $113(81.9)$ & $19(13.8)$ & $2(1.4)$ & $4(2.9)$ \\
\hline f. Feel too cold & $80(58)$ & $33(23.9)$ & $18(13)$ & $7(5.1)$ \\
\hline g. Feel too hot & $101(73.2)$ & $25(18.1)$ & $8(5.8)$ & $4(2.9)$ \\
\hline h. Have bad dreams & $51(37)$ & $52(37.68)$ & 20 (14.49) & $15(11)$ \\
\hline i. Have pain & $104(75.4)$ & $23(16.7)$ & $7(5.1)$ & $4(2.8)$ \\
\hline j. Other reason(s), please describe: & $130(94.2)$ & $4(2.9)$ & $3(2.2)$ & $1(0.7)$ \\
\hline $\begin{array}{l}\text { During the past month, how often have you taken } \\
\text { medicine to help you sleep (prescribed or "over the } \\
\text { counter")? }\end{array}$ & $132(95.7)$ & $3(2.2)$ & $2(1.4)$ & $1(0.7)$ \\
\hline $\begin{array}{l}\text { During the past month, how often have you had trouble } \\
\text { staying awake while driving, eating meals, or engaging in } \\
\text { social activity? }\end{array}$ & 106 (76.9) & $26(18.1)$ & $6(4.3)$ & $1(0.7)$ \\
\hline $\begin{array}{l}\text { During the past month, how much of a problem has it } \\
\text { been for you to keep up enough enthusiasm to get things }\end{array}$ & $\begin{array}{l}\text { No problem at } \\
\text { all }(0)\end{array}$ & $\begin{array}{l}\text { Only very slight } \\
\text { problem (1) }\end{array}$ & $\begin{array}{l}\text { Somewhat a } \\
\text { problem (2) }\end{array}$ & $\begin{array}{c}\text { Very big } \\
\text { problem (3) }\end{array}$ \\
\hline done? & $37(26.8)$ & $56(40.6)$ & $39(28.3)$ & $6(4.3)$ \\
\hline $\begin{array}{l}\text { During the past month, how would you rate your sleep } \\
\text { quality overall? }\end{array}$ & $\begin{array}{l}\text { Very good (0) } \\
\quad 31(22.5)\end{array}$ & $\begin{array}{l}\text { Fairly good (1) } \\
\qquad 82(59.4)\end{array}$ & $\begin{array}{l}\text { Fairly bad (2) } \\
20(14.5)\end{array}$ & $\begin{array}{l}\text { Very bad (3) } \\
\qquad 5(3.6)\end{array}$ \\
\hline
\end{tabular}

Table 2: Oral hygiene status of the students

\begin{tabular}{ccc}
\hline Score & Frequency (\%) \\
\hline Good & $77(55.8)$ \\
Fair & $56(40.6)$ \\
Poor & $5(3.6)$ \\
Total & 138 \\
\hline
\end{tabular}

Table 3: Association of sleep quality with oral hygiene status

\begin{tabular}{|c|c|c|c|}
\hline \multirow{2}{*}{ Oral hygiene status } & \multicolumn{2}{|c|}{$\begin{array}{c}\text { PSQI score } \\
\text { Frequency (\%) }\end{array}$} & \multirow[t]{2}{*}{ p-value } \\
\hline & $\leq 5$ & $\geq 6$ & \\
\hline Good & $48(34.7)$ & $29(21)$ & \multirow{3}{*}{0.445} \\
\hline Fair & $40(28.9)$ & $16(11.5)$ & \\
\hline Poor & $4(2.9)$ & $1(0.72)$ & \\
\hline Total & $92(66.66)$ & $46(33.33)$ & 138 \\
\hline Chi-square test & & & \\
\hline
\end{tabular}

Table 4: Association of sleep quality with self-reported academic performance

\begin{tabular}{cccc}
$\begin{array}{c}\text { Academic performance in previous } \\
\text { university exam }\end{array}$ & \multicolumn{2}{c}{$\begin{array}{c}\text { PSQI score } \\
\text { Frequency (\%) }\end{array}$} & p-value \\
Good & $\mathbf{5 5}$ & $\mathbf{2 6}$ & 0.430 \\
Poor & $25(27.17)$ & $16(34.78)$ & 138 \\
Total & $67(72.82)$ & $30(65.2)$ & $\mathbf{4 6 ( 1 0 0 )}$ \\
\hline Chi-square test & $\mathbf{9 2 ( 1 0 0 )}$ & & \\
\hline
\end{tabular}




\section{DISCUSSION}

Sleep is a physiological process essential to humans and their normal functioning. Physical, mental, and environmental factors such as age, gender, job, lifestyle, emotional tension, and noise influence sleep habits and problems. On average, between seven and nine hours of sleep each night are required by adults. ${ }^{2}$

A minimum of eight hours sleep per night is considered as the ideal amount for a good quality night's sleep according to the World Health Organisation. ${ }^{15}$ In the present study, the mean sleeping hours of the participants was seven hours. This finding is similar to studies done by Alghamdi et al. and Gilbert et al. ${ }^{16,17}$ but in contrast to the study done by Elagra et al. ${ }^{18}$ The present study was conducted to assess the association between sleeping patterns, oral hygiene status, and selfreported academic performance among dental students. The sleep quality was determined by using PSQI and it was found to be poor among 33\% of the participants which is in accordance to the studies done by Pramanik et al. ${ }^{19}$ but in contrast to the studies by Elagra, et al. and Khadka et al. ${ }^{18,20}$ Dental students are subjected to higher stress levels during their academic year leading to psychological disturbances resulting in poor sleep.

The sleeping pattern and oral health status of the participants was not found to be statistically significant in this study which is similar to the study done by Alghamdi et al. ${ }^{16}$ but in contrast to other studies. ${ }^{6,21}$

The sleeping pattern and academic qualification was also found to be statistically insignificant in the present study. The finding is similar to another study ${ }^{22}$ but in contrary to other studies. ${ }^{16,18,23}$ The contradictory finding in this study may be due to the fact that academic performance was self-reported. The relationship between common sleep disturbance and academic performance should be evaluated carefully because of the fact that

\section{REFERENCES}

1. Dewald JF, Meijer AM, Oort FJ, Kerkhof GA, Bögels $\mathrm{SM}$. The influence of sleep quality, sleep duration and sleepiness on school performance in children and adolescents: A meta-analytic review. Sleep Med Rev. 2010 Jun;14(3):179-89. [PubMed | Full Text | DOI]

2. Lawson HJ, Wellens-Mensah JT, Nantogma SA. Evaluation of sleep patterns and self-reported academic performance among medical students at the university of Ghana school of medicine and dentistry. Sleep Disord. 2019 Jun 11;2019:1278579. [PubMed | Full Text | DOI] academic success can be affected by multiple factors like family income, the evolutionary process, intake of dietary supplements and vitamins, size of the family, dependency on social media, social networks addiction, and other related social issues.

A global public health problem of college students nowadays is bad sleep quality. Irregular programming of sleep times, long naps during the day, use of alcohol before sleeping, and studying in bed are the behaviours that play an important role in sleep hygiene. ${ }^{11}$

The limitations of this study are:- The academic performances were self-reported so the reporting depended completely on the student's honesty. There can be other significant factors affecting the sleep habits, oral hygiene status, and academic performances which were not considered in this study. The students of only one dental college is taken so generalisability cannot be done. However further research should be conducted to authenticate this finding. Unequal distribution of sample size in the academic performance category might have contradicted our findings compared to other studies

\section{CONCLUSION}

The sleep pattern of dental students was found to be good. The association of sleep pattern, oral hygiene status and academic performance was found to be statistically insignificant. Further research should be conducted in this matter to authenticate the association.

\section{ACKNOWLEDGEMENT}

I would like to thank Dr. Sujaya Gupta for her immense support and all the participants of this study who participated despite the pandemic.

Conflict of interest: None.

Source(s) of support: None.

3. Chiang YC, Arendt S, Zheng T, Hanisch K. The Effects of Sleep on Academic Performance and Job Performance. Coll Stud J. 2014; 48(1):72-87. [Full Text]

4. Araújo MF, Lima AC, Alencar AM, Araújo TM, Fragoaso LV, Damasceno MM. Sleep quality assessment in college students from Fortaleza-CE. Text Context Nursing. 2013;22(2):352-60. [Full Text | DOI]

5. Orzech KM, Salafsky DB, Hamilton LA. The state of sleep among college students at a large public university. J Am Coll Health. 2011;59(7):612-9. [PubMed | Full Text | DOI] 
6. Asawa K, Sen N, Bhat N, Tak M, Sultane P, Mandal A. Influence of sleep disturbance, fatigue, vitality on oral health and academic performance in Indian dental students. Clujul Med. 2017;90(3):333-43. [PubMed | Full Text | DOI]

7. Serra-Negra JM, Paiva SM, Fulgêncio LB, Chavez BA, Lage CF, Pordeus IA. Environmental factors, sleep duration, and sleep bruxism in Brazilian schoolchildren: A case-control study. Sleep Med. 2014 Feb;15(2):236-9. [PubMed | Full Text | DOI]

8. Lohsoonthorn V, Khidir H, Casillas G, Lertmaharit S, Tadesse MG, Pensuksan WC, et al. Sleep quality and sleep patterns in relation to consumption of energy drinks, caffeinated beverages, and other stimulants among Thai college students. Sleep Breath. 2013 Sep;17(3):1017-28. [PubMed | Full Text | DOI]

9. Brockmann PE, Bertrand P, Pardo T, Cerda J, Reyes $B$, Holmgren NL. Prevalence of habitual snoring and associated neurocognitive consequences among Chilean school aged children. Int J Pediatr Otorhinolaryngol. 2012 Sep;76(9):1327-31. [PubMed | Full Text | DOI]

10. Assaad S, Costanian C, Haddad G, Tannous F. Sleep patterns and disorders among university students in Lebanon. J Res Health Sci. 2014;14(3):198-204. [PubMed | Full Text]

11. Kang JH, Chen SC. Effects of an irregular bedtime schedule on sleep quality, daytime sleepiness, and fatigue among university students in Taiwan. BMC Public Health. 2009 Jul 19;9:248. [PubMed | Full Text | DOI]

12. Bhandari PM, Neupane D, Rijal S, Thapa K, Mishra SR, Poudyal AK. Sleep quality, internet addiction and depressive symptoms among undergraduate students in Nepal. BMC Psychiatry. 2017 Mar 21;17(1):106. [PubMed | Full Text | DOI]

13. Zhong QY, Gelaye B, Sánchez SE, Williams MA. Psychometric properties of the pittsburgh sleep quality index (PSQI) in a cohort of Peruvian pregnant women. J Clin Sleep Med. 2015 Aug 15;11(8):869-77. [PubMed | Full Text | DOI]

14. Greene JC, Vermillion JR. The simplified oral hygiene index. J Am Dent Assoc. 1964 Jan;68(1):7-

\section{3. [PubMed | Full Text | DOI]}

15. Lemma S, Berhane $Y$, Worku A, Gelaye B, Williams MA. Good quality sleep is associated with better academic performance among university students in Ethiopia. Sleep Breath. 2014 May;18(2):257-63. [PubMed | Full Text | DOI]

16. Alghamdi AA, Alshahrani RA, Alzaydani A, Javali MA. Association between sleeping pattern, oral health habits and academic performance among dental students. Ann Med Health Sci Res. 2020;10:771-7. [Full Text]

17. Gilbert SP, Weaver CC. Sleep quality and academic performance in university students: A wake-up call for college psychologists. J Coll Stud Psychother. 2010;24(4):295-306. [Full Text | DOI]

18. Elagra MI, Rayyan MR, Alnemer OA, Alshehri MS, Alsaffar NS, Habib RS Al, et al. Sleep quality among dental students and its association with academic performance. J Int Soc Prevent Community Dent. 2016 Jul-Aug;6(4):296-301. [PubMed | Full Text | DOI]

19. Pramanik T, Sherpa MT, Shrestha R. Internet addiction in a group of medical students: A crosssectional study. Nepal Med Coll J. 2012;14(1):46-8. [PubMed | Full Text]

20. Khadka R, Bista S, Baskota S, Poudel L, Gurung M. Sleep quality among college students in Kathmandu valley, Nepal. Nepal Med J. 2019;2(2):1-4. [Full Text]

21. Shende AS, Bhatsange AG, Waghmare AS, Shiggaon LB, Mehetre VN, Meshram EP. Determining the association between stress and periodontal disease: A pilot study. J Int Clin Dent Res Organ. 2016;8(2):111-4. [Full Text | DOI]

22. Jalali R, Khazaei H, Paveh BK, Hayrani Z, Menati L. The effect of sleep quality on students' academic achievement. Adv Med Educ Pract. 2020;11:497502. [PubMed | Full Text | DOI]

23. Periyasamy $Y$, Priyadarshoni SP, Jayashri $P$. Prevalence of sleep disorder among dental students and correlation with oral hygiene status - A cross-sectional study. Drug Invent Today. 2019;11(Special Issue 2):1-7. [Full Text] 